\title{
INFLUENCE OF DEVELOPMENT OF COMPUTER TECHNOLOGIES ON TEACHING
}

\section{Sead Rešić1
Olgica Bešić \\ Sead Rešić
Olgica Bešić}

Department of Mathematics, Faculty of Natural Sciences, University of Tuzla

Received: 29.06 .2012

UDC: $371.3: 51: 004$

Accepted: 23.08.2012

\begin{abstract}
Our times are characterized by strong changes in technology that have become reality in many areas of society. When compared to production, transport, services, etc education, as a rule, slowly opens to new technologies. However, children at their homes and outside the schools live in a technologically rich environment, and they expect the change in education in accordance with the imperatives of the education for the twenty-first century. In this sense, systems for automated data processing, multimedia systems, then distance learning, virtual schools and other technologies are being introduced into education. They lead to an increase in students' activities, quality evaluation of their knowledge and finally to their progress, all in accordance with individual abilities and knowledge. Mathematics and computers often appear together in the teaching process. Taking into account the teaching of mathematics, computers and software packages have a significant role. The program requirements are not dominant. The emphasis is on mathematical content and the method of presentation. Computers are especially used in solving various mathematical tasks and self-learning of mathematics. Still, many problems that require solutions appear in the process: how to organise lectures, practice, textbooks, collected mathematical problems, written exams, how to assign and check homework. The answers to these questions are not simple and they will probably be sought continuously, with an increasing use of computers in the teaching process. In this paper I have tried to solve some of the questions above.
\end{abstract}

Keywords: education, multimedia systems, then distance learning, virtual schools, mathematics and computers, lectures, practice, textbooks, collected mathematical problems, written exams

\section{INTRODUCTION}

The time we live in is characterized by radical changes in engineering and technology which have come to life in various areas of society. Education, as a rule, slowly opens up towards new technologies in relation to manufacturing, traffic, service industry, etc.

\section{Correspodence to:}

Sead Rešić, Department of Mathematics, Faculty of Science, University of Tuzla

Šabana Zahirović 10, Tuzla, B\&H

Phone: +387 61101230

E-mail: sresic@hotmail.com 
Nevertheless, children live at home and outside of school in technologically rich environment, expecting changes in education in accordance to education imperatives for $21^{\text {st }}$ century.

In that sense, systems for automatic data analysis are slowly being introduced in education as well as multimedial systems, long distance learning, virtual schools and other technologies which lead to increase in students' activity, more quality in evaluating knowledge and students' advancement regarding their individual abilities and former knowledge. The guiding thought while conceptualizing and writing this paper was that our education system, particularly in elementary schools is too traditional and should be modified. The school of the present should be replaced by the school of the future where information technologies would occupy an important place, from the aspect of research, as well as multipractical aid in acquiring new and fortifying already gained knowledge through the Internet, various data in digital form, simulation programs, etc.

"Classes should be transformed into a new learning system, which implies less memorizing of facts and more studying of methods and ways through which certain facts and validities can be gained, as well as affirmation of creativity and creation... These and similar changes have been present in the world for a long time, and among other things they are supported and directed by intensive scientific and technological development..." (Hrustić, 2002., p.11). Computer as aid in the school of the future exhibits multitude of purposes and benefits:

- enables students' participation in programed classes, which induces in a child the will to acquire more knowledge

- encourages and develops creative characteristics in student's personality

- facilitates performing everyday teachers' obligations, since this matter of class - conduction is possible for all subjects and units (analysis, revision, repetition, exercise,...)

- poses new roles of students and teachers

- makes evaluation during class, etc.

\section{NECESSITY OF INCLUDING INNOVATIVE TEACHING AND ITS AIMS}

When talking about pedagogical innovation, we may refer to adapting the school (school system) to social-economic, scientific-technological and other changes, demands of general development in society and our knowledge about development of children (pupils/students).

"The following innovation should be introduced in our schools: individualized classes, multilevel classes, problem targeted classes, computer assisted classes, cabinet, programed, team classes, etc." (Hrustić, 2002., p.80).

Computer application as innovation classes would enable the following:

- to reduce and acquire quicker and easier overly wide curricula,

- it would impose modern and contemporary content upon the traditional one,

- memorizing would give place to thinking, and conformity to critical thinking and flexibility,

- uniform formats would provide more space for various studying styles,

- the role of student and teacher would change,

- The teaching process would significantly be embedded with technical, technological, methodical and other novelties, etc.

\section{MODELS OF COMPUTER INTEGRATING IN THE TEACHING PROCESS}

In order to successfully integrate computer technology in the teaching process, hardware and software are not a problem. Students are mostly thrilled and accept learning from electronic learning. Taken that adequate software and hardware were chosen, the success on this technology depends on the way it is implemented.

Considering the current condition in our school system, the following models of integrating personal computers in the teaching process can be abstracted: 


\section{The traditional model}

The traditional model contains all the elements of the classical classes: fixed place and time, classroom without computer, while the Internet is additional resource which students may use in the computer cabinet during the hours or their free time. The traditional model introduces the Internet in the teaching process and uses it as the alternative information source.

\section{The transitional model}

The transitional model keeps the traditional elements of fixed place and time, but the place can encompass regularly planned visits to the computer cabinets. This model may also enable the teacher to eliminate spatial limitations by using electronic mail or chat clients for synchronic and asynchronic exchanges (conference calls); that is, students from remote locations can participate in classes.

\section{The distance teaching model}

This model surpasses the limits of the traditional classes by embedding the entire material, exercises and resources online. Students do not have to come to school for a classical class; instead, they exchange ideas and information entirely through the Internet, with possible exceptions regarding orientation sessions, official classes or supervised exams.

\section{COMPUTERS IN INCLUSIVE CLASSES}

Education system, which is created according to our standards, almost completely neglects children with special needs, forgetting that they too have to bear everyday life. Indeed, they wish to cope with it and be as productive as everyone else.

Information and communication technologies can not only enable these children more accessible learning, but can also by their nature be more accessible for persons with special needs. Computers can greatly expand the horizons of these children, and display options with special accessibilities in order to employ available technologies more efficiently. Computer can also be adjusted to the needs and abilities of students - graphical user interface (GUI), and input devices may be attuned in order to fully satisfy the needs of users. It is considered that a computer is something the user should adjust to in order to use it, while in fact, many alterations can be made to increase the accessibility. Texts size can be enlarged as well as screen contrast, audio announcements may be visually shown, keyboard and pointing devices can be adjusted in order to fit various settings for computer usage, etc.

There are already companies on the market which deal with production hardware and software such as Microsoft, and they take into account care about people with special needs. They greatly facilitate and provide a great number of possibilities for a more productive life and a life where communication is easier.

Information and communication technologies have that potential to significantly change the way of life for persons with special needs.

\section{COMPUTER IN MATHEMATICS TEACHING}

In mathematics teaching on all levels: in elementary and high school, at colleges and universities, we are faced with disconcerting situations. Mathematicians are debating and writing about what pupils and students could and should study. At the same time pupils and students are struggling with the basic problems:

-how to learn the language of mathematics, -how to accept mathematical models and mathematical thinking processes.

There are different manners to influence the overcoming of this uncomfortable situations. Books are being written which provide examples - "patterns" for solving great number mathematical problems. Mathematics teachers give simpler tests and written exams, much easier than those that could be solved based on subject matter prescribed by the curriculum. It is usually considered that the problem in mathematics teaching lies in pupils and students, not in the lack of communication between them and mathematics teachers. It is commonly said that pupils and students do not accept all that is being offered to them through classes or that they are completely disinterested for mathematics classes.

Those who are not specialized in mathematics are not even attempting to resolve problems in mathematics teaching, while mathematicians often shrug to show that this is not their fault. 
American mathematician Mac Lane offered the following string of actions which can help understand mathematics:

intuition - trial - error - contemplation - presupposition - proof

(S. Mac Lane, Responses to theoretical mathematics ..., Bull. Amer. Math. Soc. (N.S.)

This is in contradiction with overall practice of conducting mathematics classes in almost all schools and universities:

\section{lecturing - memorizing - exam}

Many a mathematician who actively work within mathematics as a science, are in agreement with Mac Lane's opinion that the manner in which mathematics is studied and operated does not equal the manner in which it is taught in schools and universities.

This poses the following questions:

- Can mathematics be taught in the manner it is studied?

- Can interest in mathematics be increased, and if there is none, can it be incited?

- What is the role of computers regarding the two previous questions?

Contemplations of the mathematician Davis will be provided in reference to the role of computers in teaching mathematics and possibilities they offer regarding the posed questions. He believes that the possibilities of research in mathematics have significantly improved thanks to computers. Even with great assistance which computers offer in all areas of mathematics, the mathematicians still have the leading role.

This can be put even more precisely: mathematics develops in such a way that the role of mathematicians is always manifested. Regarding education, Davis believes that the classical approach of teaching and proving must share both space and time with other manners of acquiring and presenting mathematical content. He also believes that in mathematics textbooks that the slightly boring way of presenting based on strict proof must be modified (P. J. Davis, The rise, fall, and possible transfiguration of triangle geometry: a mini-history Amer.Math.Monthly).
It is important to mention that the students' work without computers in a no way neglected by employing computers in mathematics teaching. On the contrary, employing computers stimulates the most important aspect in teaching mathematics, and that is understanding the subject matter. Pupils or students no longer have to learn by heart great numbers of formulas, are no longer afraid making a mistake in calculation, so their entire attention is drawn to understand problems and tasks. A large problem in mathematics teaching without computers, in schools as well as universities, is application to a small number of problems.

Teacher or professor also meets difficulties while choosing examples of classes and task preparing tasks for knowledge evaluation since it necessary to assemble with "nice solutions." With the use of computers, most of the above mention limitations is entirely eliminated and students acquire better image about the significance of mathematics and its applications.

\section{CURRENT REPRESENTATION OF COM- PUTER APPLICATION IN MATHEMATICS TEACHING}

Considering the way of presenting one subject unit in mathematics in an average school in Bosnia and Herzegovina today, the conclusion follows that this way of presenting is in not much different from the way of presenting twenty years ago. Teaching math ematics in Bosnia and Herzegovina is founded on traditional basis, related to the blackboard, chalk and frontal manner of teaching. Despite aspiration to place the student at the center of education, focus has, for the most part, shifted on the teacher. As yet another downside of this kind of teaching is that one way communication between teacher and student, as well as insufficient students' activity.

If, on the other hand, the students, their environment, lifestyle, aspirations and interests are observed, a significant difference can be notices between students today and twenty years ago. 
Today, students are exposed to various multimedia contents which can be found everywhere, television, commercials, billboards, mobile phones, computers, the Internet, Today students are overwhelmed with information and their attention is directed towards various contents. In such environment it is necessary to improve and innovate classes so as to make them more acceptable, interesting and useful for students.

\section{Research: How much do we use computers in mathematics teaching today}

\section{Teachers}

This research included forty-five elementary school mathematics teachers of different ages, in the Tuzla Canton area. The aim of this part of the research is forming an image about using computers in mathe- matics teaching process in elementary education, as well as about teachers' attitudes. In reality, the idea is to find out from this part of research how much teachers employ information technologies during classes, but also to examine to what extent they give homework that demands using a computer. Also, the aim is to examine teachers' attitudes about availability of resources in their schools, which are relevant for conducting multimedial classes. Alongside with this the position of teachers, as well as their desire to use computers more everyday teaching process was examined. This research also examined the confidence of teachers towards The Faculty of Natural Sciences and Mathematics as an institution which can provide adequate assistance and support. The research was conducted through survey. The survey consisted of five closed type questions. The survey was anonymous.

\section{Survey results}

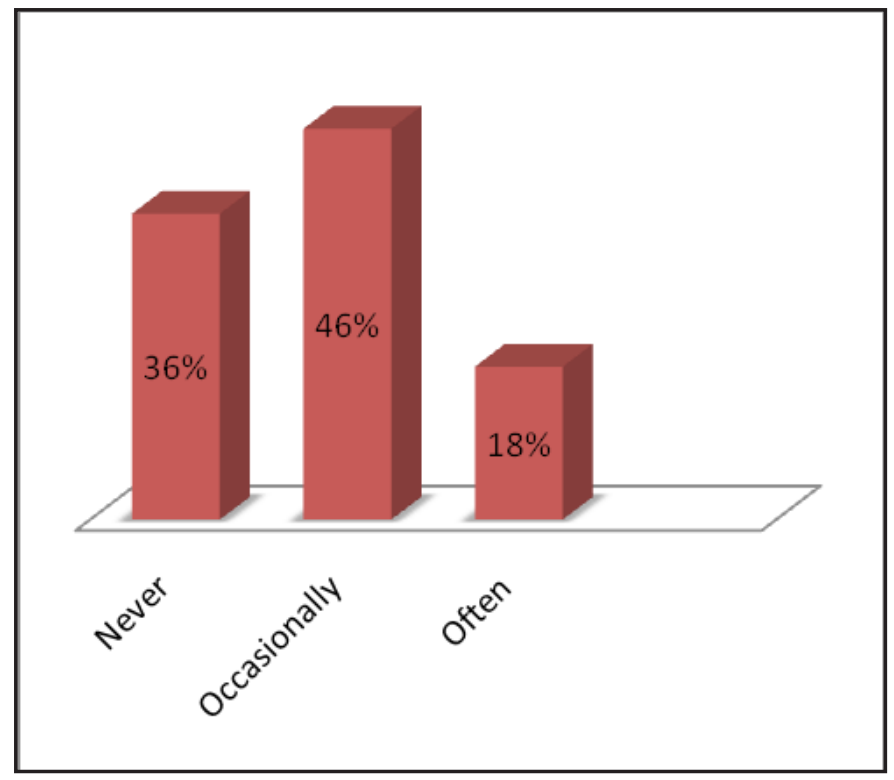

Figure 1. Responses to the question "Do you use a computer in classes?"

Results presented on the graph clearly point to weak representation of computers in classes. The mentioned data leads to the conclusion that the percentage of teachers who have never used a computer (36\%) is twice bigger than the percentage of those who frequently use a com- puter (18\%). During the survey $46 \%$ of teachers claimed that they use computers in class from time to time, and it should be noted that teachers opted for the answer "from time to time" even if they use computer only once while teaching in the entire school year. 


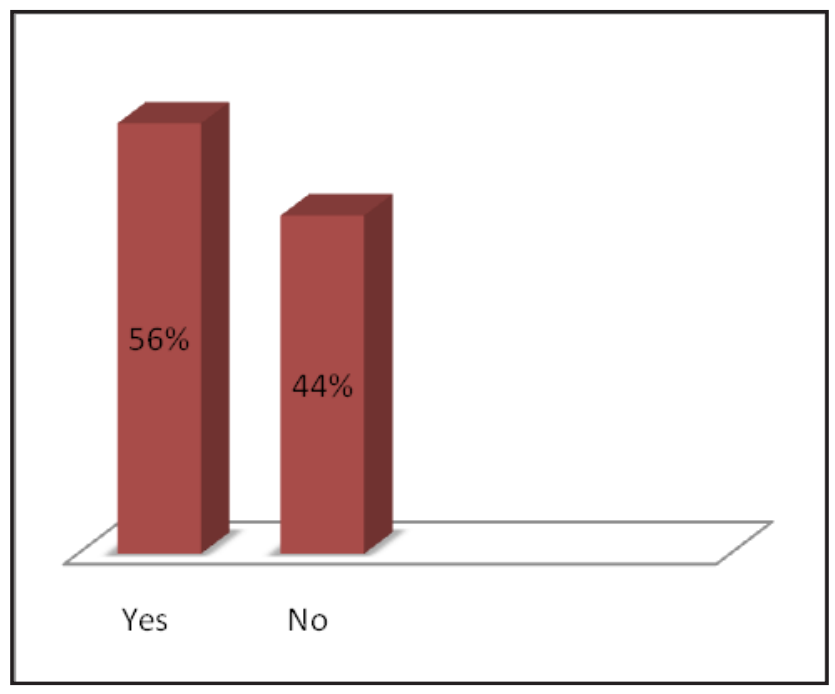

Figure 2. Responses to the question "Would you like to use a computer more in classes?”

The presented results show positive attitude of most teachers when it comes to including computers in the teaching process. There is also a great percentage of teachers who do not wish to have computers in their classes. The reason for this kind of resistance in teachers could be the fear of something new and unknown, as well as a change in routine considering their manner of teaching.

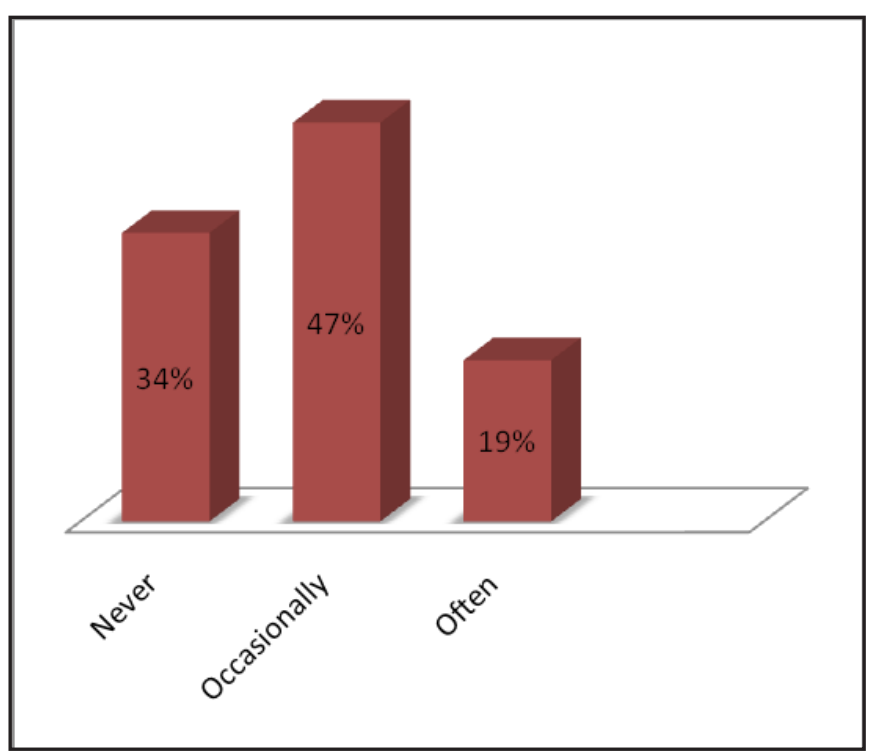

Figure 3.Responses to the question "Do you give homework that demands using a computer?"
Considering the fact that $34 \%$ examinees answers "never", 47\% answered "occasionally" and 19\% "frequently", extraordinary similarity in percentages compared with the previous question is noticeable. Based on the figures a hypothesis can be set that the two previous questions are correlated. Also, based on the two previous graphs it can be concluded resource availability, i.e. the equipment with information technologies in schools largely has no significance for improving classes with the use of computers.

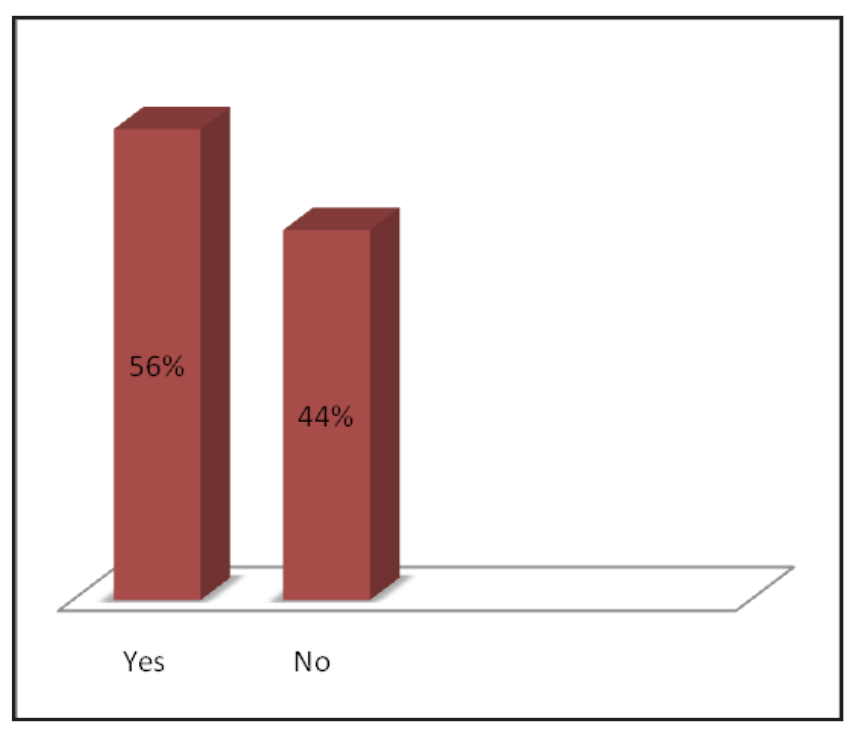

Figure 4. Responses to the question "Would you benefit from the assistance of Faculty for Natural Sciences and Mathematics as an institution which can provide adequate expert help related to using computers in mathematics teaching?"

The results of this survey question are equal to those for the question: I would like to use computers more in classes, which implies teachers who wish to use computers more in the teaching process also exhibit confidence in the Faculty for Natural Sciences and Mathematics, as an institution which can provide assistance and support during professional specialization. 


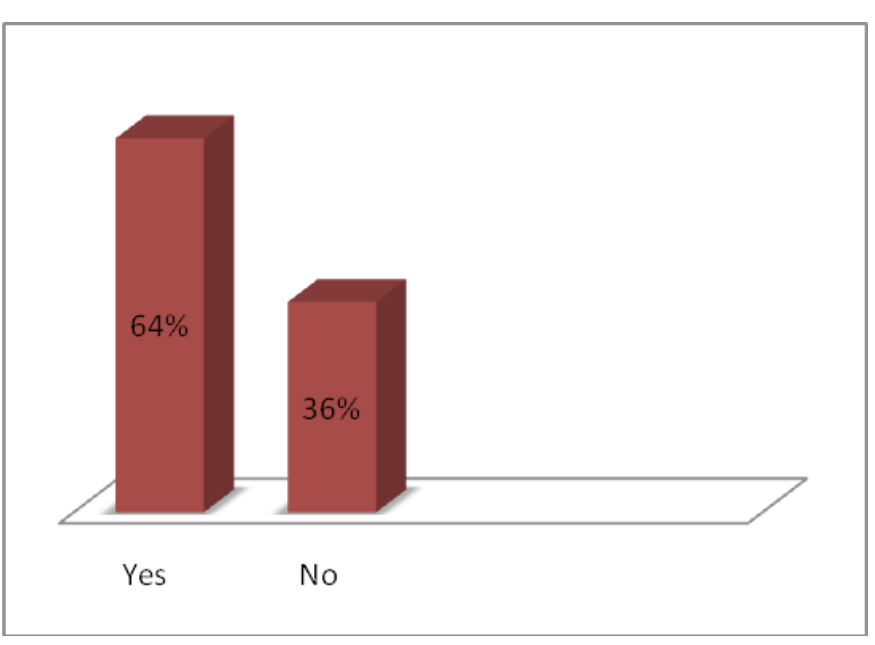

Figure 5. Responses to the question "Are there, in schools where you are employed, solid conditions for using computers in mathematics teaching?"

Most teachers believe in schools where they are employed there are conditions for using computers. Obviously, most schools own at least the minimum of technical requirements sufficient for conducting classes with usage of computers. However, the mere percentage of $36 \%$ of schools that do not have the necessary requirements for conducting classes using computers is troublesome.

\section{Students}

\section{The aim of research}

The aim of this part of research is forming an image regarding students' attitudes towards implementing computers in the teaching process. It is expected that the findings of this research will provide information related to the quantity of computer usage by students to which purposes. Also, in this part of research previous experiences of students related to classes that demand using information technologies were examined, as well as their familiarity with the software that can be used in educational purposes. Students were questioned individually or in pairs. They were encouraged to bring out their opinions and formulate answers to the posed questions. Audio recordings of this part of research were analyzed using content analysis method. The sample encompasses students in sixth, seventh and eighth grade of elementary school.
In this part of research thirty students from elementary school "Bukinje" - Tuzla took part. The criterion for choosing students is their expressiveness and communicability.

Students replied to the posed questions:

1. How often do you use a computer?

2. How much time do you spend in front of a computer during the day?

3. Do you use the Internet?

4. What kind of content do you watch on the Internet?

5. Besides the Internet what is your computer useful for?

6. Do you use the computer for educational purposes? How? Which ones?

7. Have you ever processed a teaching unit at school using computers, safe from informatics class?

8. Do you remember what you learned during that class? Was it interesting?

9. Do teachers give you homework assignments which demand using a computer (the Internet)? Are those assignments difficult?

10 . Do you have any program on your computer which is useful for school?

\section{Responses resume}

Students largely put accent on the Internet as the reason for using a computer. It is interesting that students spend a bulk of their time on the Internet while actually visiting a small number of Internet sites. They are not familiar with many sites which they can use in educational purposes. They spend most of their time on social networks. When it comes to educationally useful software, students mostly express no knowledge about them or gave short and simple answers.

Students were very motivated to answer the posed questions. They were excited to talk about impressions from classes when they use computers. According to students, there were very few of such classes, but they are well- remembered and almost all students had positive impressions. 
Students expressed positive attitudes toward including computers into teaching process. They realize many advantages of that manner of learning, but certain students are aware of possible difficulties that can occur while including computers in the teaching process.

\section{THE MANNERS OF APPLYING COMPUTERS IN TEACHING MATHEMATICS}

The manners of applying computers in teaching mathematics are related to representing teaching units or their parts through:

- presentation

- video footage

- programs

- mathematical games

- ready - made software, etc.

These manners of application may be used regardless of the type of class (presentation, revision, and systematizing).

\section{Presentations}

Through presentations it is possible to present all subject units in mathematics in a very original or interesting. Preparation of presentations is very simple, so this type of computer usage in teaching mathematics does not require additional training for a teacher. Image 1 - Image 4

\section{Video footage}

Through video footage it is possible to interpret parts of subject matter and/exercises which, due to their length, difficulty, cannot be performed during class with utmost quality. It is also possible to use short films or other recordings to present historical facts about life and work of certain mathematicians, which are extremely motivational for the children. This manner of work is very interesting for students.

\section{Fractions - revision}

Presentation for subjeet mattor rovision (fraetions) for $5^{\text {th }}$ and $6^{\text {th }}$ grados

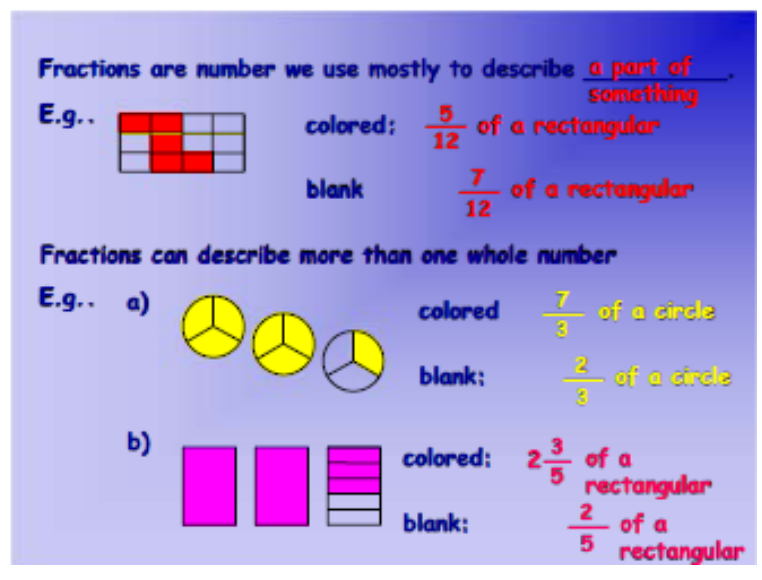

Parts of a fraction

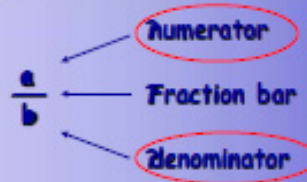

Denominator tells us on how mamy equal parts we divide the object. Enumerator tells us how mamy parts we should color.

We used these characteristics of numerator and denominator in previous examples.

Fraction bar equals dividing.

E.g. $\frac{8}{4}=8: 4=2$

Image 1 - Image 4. Part of the presentation of subject unit Revision, topic 'Fractions'-5th and 6th grades. 


\section{Programs - Programed teaching}

Program teaching stems from Socratic teaching ancient Greece. The first programmer in the area of geometry was Socrates. In programed teaching, the program precisely lays out all the important facts and concepts that students should learn. The subject matter is divided into logically connected units which are easy and small enough, and they are being mastered one after another. In order for students to start mastering the mentioned subject matter, they must acquire knowledge from prior subject units. Subject matter cannot be skipped. The role of the teacher, especially expressed during creating programmed or semi-programmed materials. During the students' work in class the teacher will follow up the process of completing the tasks, provide additional information and explanation for work, etc.

\section{Games in mathematics}

The guiding idea for many good mathematics teachers while working with students in implementing Polya's scheme in the teaching process. If a student is properly included in the world of mathematical games, they can be guided through the four stages tantamount to stages suggested by Polya. In the first stage students should understand the rules of the mathematical game which is analogous to understanding text of the task. In the second stage it is expected that the student should provide a plan of game. Research has shown that during every consequent playing of the same game, students remain longer in this stage so as to find the winning strategy. The third stage comes down to making the correct move in the game. In the final stage, after the game is over, the students are allowed to see the game process. This possibility drags them to think how to discover the winning strategy.

Using mathematical games serves to successfully remove the lack of motivation in teaching mathematics, since the well-expressed affinity of children of playing is used significantly.

\section{EVALUATING AND GRADING STUDENTS' KNOWLEDGE}

Evaluating and grading through computer is mostly designed so that certain tests, papers or exercises are to be completed according to suggested model, even though it can be conducted through other manners of evaluating. Every piece of work should be leveled and have clearly defined measuring object. It must be defined what the work is measuring and with what accuracy, objectivity and consistency. Evaluations of students' knowledge using a computer have their upsides and downsides. Besides being economical, these kinds of works enable more objective and reliable assessment of classwork then with other types of examining. Also, they enable comparison of results between different students as well as comparison of achievements for the same student in different periods of examining.

One of the greatest weaknesses of this type of evaluation is that it measures only what is shown, only that the student managed to write or show at a particular moment, but it does not measure the implicit part of knowledge that subtle understanding of subject matter that a teacher can sense during other types of examining. Another weakness is also the fact that this way it is difficult to measure attitudes and interests of students.

\section{POSITIVE AND NEGATIVE FACTORS IN USING COMPUTERS IN MATHEMATICS TEACHING}

\author{
Positive factors: \\ - individual approach enabled, \\ - offers efficient feedback, \\ - capacitate student for individual work, \\ - the position of students and teachers is altered,
}

Negative factors:

- classes are schematized (limited imagination, creativity, originality),

- it is acceptable for students with modest intellectual capabilities, 
- limited personal communication - social isolation,

- all parts of subject matter are not equally applicable for presentation via computer

- induces the phenomenon of electronic memorizing in students (children got used to easements when using computer technologies, so they do not even attempt to memorize, calculate something, etc, which leads to ever worse results in mathematics teaching $-60 \%$ of eight graders do not know by heart their parents' birthdays and 43\% telephone numbers).

\section{RESEARCH - COMPUTERS IN MATHE- MATICS TEACHING (YES/NO)}

In June 2012, in elementary school "Bukinje" Tuzla computer supported classes presentation, revision, and evaluation of subject units in subject mathematics in the seventh grade. The classes took place with a group of 24 students also present during classes were colleagues - teachers for other subjects and the school pedagogue. Their observations are presented in Tables 1 and 2.

Table 1. Results of students'survey

\begin{tabular}{|c|c|c|c|c|}
\hline \multicolumn{2}{|c|}{ Questions } & \multirow{2}{*}{$\begin{array}{l}\text { Answers 'YES' in } \\
\text { percentages (\%) }\end{array}$} & \multirow{2}{*}{$\begin{array}{l}\begin{array}{l}\text { Answers 'NO' in } \\
\text { percentages (\%) }\end{array} \\
4,16 \\
\end{array}$} & \multirow{2}{*}{ Other } \\
\hline 1. & Did you like the previous class? & & & \\
\hline 2. & $\begin{array}{l}\text { Would you like to replace classical classes (teacher, } \\
\text { presentation, blackboard, chalk) with this kind of } \\
\text { classes? }\end{array}$ & 87,5 & 12,5 & \\
\hline 3. & Do you believe it is is interesting to learn this way? & 91,67 & 8,33 & \\
\hline 4. & $\begin{array}{l}\text { Should classes in all subjects be conducted this or } \\
\text { similar way (meaning other picturesque programs } \\
\text { depending on the subject)? }\end{array}$ & 87,5 & 12,5 & \\
\hline \multirow[t]{4}{*}{5.} & \multirow[t]{4}{*}{ How often should you have classes like this? } & All the time & \multicolumn{2}{|l|}{79,18} \\
\hline & & Often & \multicolumn{2}{|l|}{12,5} \\
\hline & & Rarely & \multicolumn{2}{|l|}{4,16} \\
\hline & & Never & \multicolumn{2}{|l|}{4,16} \\
\hline 6. & $\begin{array}{l}\text { Do you believe that you encompassed (learned) the } \\
\text { subject matter in this class with more quality because } \\
\text { it was presented in a different way? }\end{array}$ & 87,5 & 12,5 & \\
\hline 7. & $\begin{array}{l}\text { Do you think that the subject matter you leamed this } \\
\text { way will stay longer in your memory? }\end{array}$ & 91,67 & 8,33 & \\
\hline 8. & $\begin{array}{l}\text { Would your success be better if you did written exams } \\
\text { (tests, papers, exercises) in this manner? }\end{array}$ & 75,00 & 25,00 & \\
\hline 9. & $\begin{array}{l}\text { If you think it is necessary, write your opinion about } \\
\text { the previous class! }\end{array}$ & & & \\
\hline
\end{tabular}


Table 2. Results of teachers'survey

\begin{tabular}{|c|c|c|c|c|}
\hline \multicolumn{2}{|c|}{ Questions } & \multirow{2}{*}{$\begin{array}{l}\text { Answers 'YES' in } \\
\text { percentages (\%) } \\
75\end{array}$} & \multirow{2}{*}{$\begin{array}{l}\text { Answers 'NO' in } \\
\text { percentages (\%) } \\
\mathbf{2 5}\end{array}$} & \multirow{2}{*}{ Other } \\
\hline 1. & $\begin{array}{l}\text { Did you like the way the previous class was } \\
\text { conducted? }\end{array}$ & & & \\
\hline 2. & $\begin{array}{l}\text { Would you like to replace your classical classes with } \\
\text { these or similar innovative methods of class } \\
\text { construction? }\end{array}$ & 75 & 25 & \\
\hline 3. & $\begin{array}{l}\text { Do you consider that it is more interesting for students } \\
\text { to learn this way? }\end{array}$ & 100 & 0 & - \\
\hline 4. & $\begin{array}{l}\text { Do you believe that your work would be easier using } \\
\text { these methods of teaching? }\end{array}$ & 100 & 0 & \\
\hline 5. & $\begin{array}{l}\text { Should classes in all subjects be conducted this way or } \\
\text { similarly, even with different and more picturesque } \\
\text { programs (depending on the subject)? }\end{array}$ & 75 & 25 & \\
\hline \multirow[t]{4}{*}{6.} & \multirow[t]{4}{*}{ How often should pupils have this kind of classes? } & All the time & \multicolumn{2}{|l|}{25} \\
\hline & & Often & \multicolumn{2}{|l|}{50} \\
\hline & & Rarely & \multicolumn{2}{|l|}{25} \\
\hline & & Never & \multicolumn{2}{|l|}{0} \\
\hline 7. & $\begin{array}{l}\text { Do you believe that every student mastered with more } \\
\text { quality the subject matter elaborated in the previous } \\
\text { class because it was presented using the visualization } \\
\text { method (demonstration) more than presentation? }\end{array}$ & 50 & 50 & \\
\hline \multirow[t]{4}{*}{8.} & \multirow{4}{*}{$\begin{array}{l}\text { In the case that the previous question was answered } \\
\text { with 'no', tell us: How many students (in percentages) } \\
\text { will in your opinion master the subject matter with } \\
\text { more quality? }\end{array}$} & $0-25 \%$ & \multicolumn{2}{|l|}{0} \\
\hline & & $26-50 \%$ & \multicolumn{2}{|l|}{0} \\
\hline & & $51-75 \%$ & \multicolumn{2}{|l|}{100} \\
\hline & & $76-100 \%$ & \multicolumn{2}{|l|}{0} \\
\hline 9. & $\begin{array}{l}\text { Do you believe that subject matter learned this way } \\
\text { will remain in students' memory longer? }\end{array}$ & 75 & 25 & \\
\hline $\begin{array}{l}1 \\
\mathbf{0} .\end{array}$ & $\begin{array}{l}\text { Would you agree to allow students to do written } \\
\text { exams in your subject (tests, papers, exercises etc.) } \\
\text { this way? }\end{array}$ & 50 & 50 & \\
\hline $\begin{array}{l}1 \\
1 .\end{array}$ & $\begin{array}{l}\text { Would these types of written exams and evaluation be } \\
\text { more objective than the classical ones? }\end{array}$ & 75 & 25 & \\
\hline 1 & $\begin{array}{l}\text { If you think it is necessary, write your opinion about } \\
\text { the previous class! }\end{array}$ & ב-ב & -ב & \\
\hline
\end{tabular}

\section{CONCLUSION}

Well-prepared and expert mathematics teaching with the help of a computer can enable new ways of schooling and significantly facilitate the teachers' job. Therefore, the conclusion derived would be that computer technologies could greatly facilitate the very manner of knowledge transfer, as well as, accepting it, so the results after tests would be much better. In any case, combining the prior manner class conducting and computer technologies would provide excellent results in an easier way of presenting the subject matter, as well as, in better understanding by the students.

\section{REFERENCES}

Hrustić, F. (2002). Obrazovanjem u budućnost [Education in the future], B\&H, Sarajevo.

MacLane, S. Responses to theoretical mathematics ..., Bull. Amer. Math. Soc. (N.S.)

Davis, P. J. (1995). The rise, fall, and possible transfiguration of triangle geometry: a mini-history. Amer. Math. Monthly $102,204-214$. 